Goldschmidt 2021 Abstract

https://doi.org/10.7185/gold2021.8188 post-collisional stages of Variscan orogeny, are thus responsible for the Mesozoic magmatism of the Southern Alps.

\section{Orogenic to anorogenic signatures in Mesozoic intra-plate magmatism: Evidence from alkali-rich dykes in the Finero Phlogopite Peridotite (Ivrea- Verbano Zone, Southern Alps)}

\author{
ABIMBOLA CHRIS OGUNYELE ${ }^{1}$, TOMMASO \\ GIOVANARDI ${ }^{2}$, MATTIA BONAZZI ${ }^{3}$, MAURIZIO \\ MAZZUCCHELLI $^{2}$ AND ALBERTO ZANETTI ${ }^{4}$ \\ ${ }^{1}$ UNIVERSITÀ DEGLI STUDI DI PAVIA, DIPARTIMENTO \\ DI SCIENZE DELLA TERRA E DELL'AMBIENTE \\ ${ }^{2}$ Università degli Studi di Modena e Reggio Emilia \\ ${ }^{4}$ Istituto di Geoscienze e Georisorse - Consiglio Nazionale delle
}

${ }^{3}$ University of Pavia Ricerche

Presenting Author: abimbola.ogunyele01@universitadipavia.it

The Ivrea-Verbano Zone (IVZ, westernmost sector of the Southern Alps) represents a unique opportunity to investigate the Paleozoic to Mesozoic post-collisional evolution of the Variscan realm from the perspective of the lower continental crust. To place further constraints on such issue, dyke swarms cropping out in the Finero Phlogopite Peridotite mantle unit have been investigated. Dykes are from few $\mathrm{cm}$ to $60 \mathrm{~cm}$ thick, and cut at high angle the mantle foliation and rock layering formed by Paleozoic deformation and melt migration. They are composed by coarse-grained hornblendite to anorthosite, both phlogopitebearing. Many dykes are composite, showing variable proportions of hornblendite and anorthosite. Dykes were largely affected by volatiles overpressure during late magmatic stages, which also produced plastic flow and development of a porphyroclastic structure by deformation of early cumulates, with widespread segregation of a fine-grained mica matrix.

A dyke series is characterized by Al-rich amphibole compositions (pointing to sadanagaite end-member) and metasomatic sapphirine. The amphiboles show large LILE and LREE contents, but negative $\mathrm{Nb}, \mathrm{Ta}, \mathrm{Zr}$ and $\mathrm{Hf}$ anomaly and isotopic oxygen composition heavier than the mantle interval, supporting the occurrence of continental crust components in the parent melt.

Another dyke series consists of pargasite, phlogopite and albite (An 8-10), in association with apatite, monazite, ilmenite, zircon, Nb-rich oxides and carbonates. Enrichments in $\mathrm{Fe}$ (amphibole and phlogopite) and $\mathrm{Na}$ (plagioclase) suggest segregation from evolved melts, strongly enriched in $\mathrm{H}_{2} \mathrm{O}, \mathrm{P}$ and C. Amphiboles are enriched in LILE and LREE, but also in $\mathrm{Nb}$, $\mathrm{Ta}, \mathrm{Zr}$ and Hf. This geochemical evidence, as well as the mineral assemblage, indicate an alkaline affinity of the parent melt. The strongly positive $\varepsilon \mathrm{Hf}_{\mathrm{t}}(+10)$ of zircons and the isotopic $\mathrm{Sr}$ composition of amphiboles in this dyke series point to mildly enriched mantle sources.

Zircons are mostly anhedral, with homogenous internal structure or sector zoning. Concordant ${ }^{206} \mathrm{~Pb} /{ }^{238} \mathrm{U}$ zircon ages vary from $221 \pm 9$ Ma to $192 \pm 8$ Ma. Heterogeneous mantle sources, possibly including continental crust delaminated during 